\title{
PRINCIPALII DĂUNĂTORI ALE CULTURII NUCIFERE DIN CLASA ARACHNIDA ŞI MANIFESTAREA EFECTELOR NEGATIVE ALE ACESTORA
}

\author{
Crucean $S$. \\ Institutul de Genetică, Fiziologie și Protecție a Plantelor; Chișinău; Republica Moldova. \\ stefan.ace681@gmail.com
}

https://doi.org/10.53040/9789975347204.04

\begin{abstract}
This material results from the research of the nut culture in order to identify pathogenic organisms of the class Arachnida and to represent the effects of these organisms on tree organs. The research was made at the Botanical Garden Institute, Chișinău on a number of 300 trees. This paper includes the identification of the main pests of the class Arachnida, namely: the gall mite of walnut leaves (Aceria tristriata) and the disease named walnut blister mine caused by Aceria erinea. At the same time, the methods of pest control and the negative effects of their presence are exposed here.
\end{abstract}

Key words: Walnut, leaves, mites, Aceria tristriata, diseases, Aceria erinea.

\section{Introducere}

Nucul este una dintre cele mai importante specii pomicole. Miezul de nucă este un aliment concentrat cu o compozitie complexă de substanțe proteice, substanțe grase, glucide, celuloză, potasiu, Mg, Ca, Fe, P, Zn, Cl. Nucul este originar din Asia Centrală și din unele zone ale Peninsulei Balcanice, majoritatea botaniștilor apreciază că acesta și-ar avea originea în Persia (Iran). Nucul spontan se găsește în Estul si Sud-Estul Asiei, precum și în regiuni întinse din masivul Himalaya, trecând apoi în China. În cultură este cunoscut din timpuri 
vechi, la început în China. Astfel, cultura nuciferă s-a extins mult în afara arealului său natural, găsindu-se, în prezent, aproape în toate țările cu climă temperată. [1]

Republica Moldova, la capitolul creșterii și multiplicării culturii nucifere la fel poate fi atribuită printre statele care ocupă locurile de frunte. Încă la începutul secolului XX statul își asigura consumul intern, iar pentru export, cifra depășea 5,4 mii de tone de nuci de calitate superioară. [2]

În 2015, Statele Unite a fost furnizorul numărul unu de nuci, atât cu coajă, cât și fară în UE, iar Moldova ocupă cu mandrie locul al doilea. R. Moldova are condiții climatice și pedologice ideale pentru producția de nuci - se situează în cele 7\% din teritoriul mondial care se socoate cel mai potrivit pentru productivitatea maxima a varietății superioare de nuc Juglans regia, astfel conturând importanța culturii nucului pentru Republica Moldova. [3]

În așa fel, o perioadă îndelungată s-a considerat că acest tip de cultură nu posedă boli şi dăunători; astfel lucrarea dată vine să prezinte susceptibilitatea pomilor nuciferi asupra reprezentaților din clasa Arachnida și ale efectelor negative ale acestor reprezentanți.

\section{Materiale și metode}

La capitolul materialelor și a metodelor utilizate în cercetare, au folosit drept sursă livada de cultură nuciferă din cadrul Institutului Grădinii Botanice din or. Chișinău, asupra unui număr de aproximativ de 300 de pomi (De Vălcineț, Suvenir (27-2), Codrene (B-24), Lunguiețe (B-14), Chișinăuine (13-6), Dudui (Mhl-924), Micleușene (14-2), Nistrene (Cib.-3), Dolna (D-3), De Buiucani (B-10). În cadrul elaborării materialului au fost utilizate surse de literatură de origine atât națională, cât și internațională. Studiul a fost realizat în perioada 06 aprilie -26 august.

\section{Rezultate și discuții}

Galele (cecidiile) sunt excrescenţe anormale ale ţesutului plantei, neoformaţiuni proliferative localizate [4]. Celulele plantelor sunt stimulate să crească în mărime şi/sau în număr de către activităţile de hrănire, secreţiile chimice şi/sau simpla prezenţă a organismelor străine (inducători de gale, organisme galigene sau organisme cecidogene). Aceste organisme sunt de obicei insecte sau acarieni, dar pot fi şi: fungi, nematode, bacterii sau virusuri.[5]

Drept dăunătorii principali din clasa Arachnida care manifestă efecte negative asupra pomilor cu culturi nucifere, sunt:

Acarianul galicol al frunzelor de nuc (Aceria tristriata) apare frecvent pe frunzele culturii nucifere. Acarianul este un păianjen microscopic, viermiform și este de culoare albicioasă translucidă.

Semnele atacului sunt vizibile pe ambele părți ale frunzelor de nuc. Atacul se manifestă sub forma unor gale (cu aspect protuberant) rotungite de 1-2 mm, care la faza apariției au o culoare predominantă galben - verzuie; după care, pe perioada dezvoltării se obsevă distins colorarea acesteia în culoarea roșie.

Acarianul afectează cultura nuciferă sub pragul economic de dăunare, iar unica daună produsă culturii se manifestă prin deteriorarea aspectului frunzelor.

La compartimentul combaterea dăunătorului, tratamentele trebuie efectuate până la apariția simptomelor (galelor) prin aplicarea acaricidelor specifice. Drept acaricide utilizate pot fi propuse preparatele: Pelecol ( compus din esterii etilici ai acizilor grași din ulei de rapiță, 490 g/l) - elaborat de către savanții din cadrul Institutului de Genetică, Fiziologie și Protecție a plantelor și Thiovit Jet 80 WG (sulf, 800 g/kg) elaborat în Elveția.[6] 
Erinoza (brasicarea) frunzelor de nuc (Aceria erinea sp.) acarianul este un păianjen microscopic viermifor de culoare galben deschisă, chiar albicioasă. Ouăle depuse sunt de formă sferică; femela depunând circa 80 de ouă în 30 de zile de activitate (viețuire) [7].

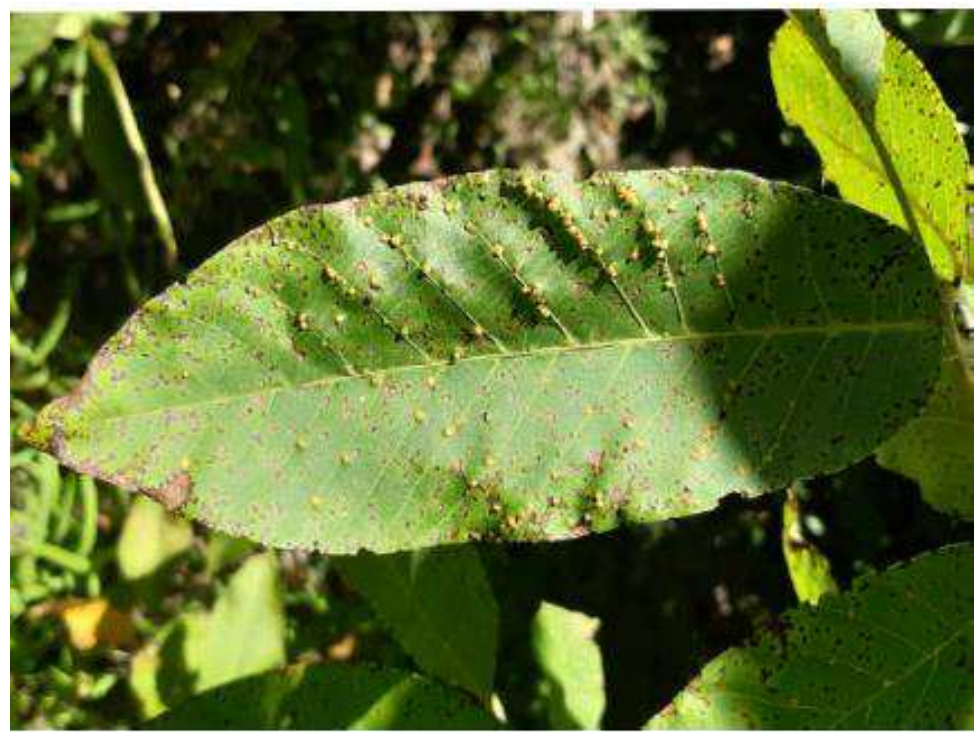

Fig. nr. 1. Reprezentarea acarianului galicol al frunzelor de nuc (Aceria tristriata) pe partea anterioară a frunzei.

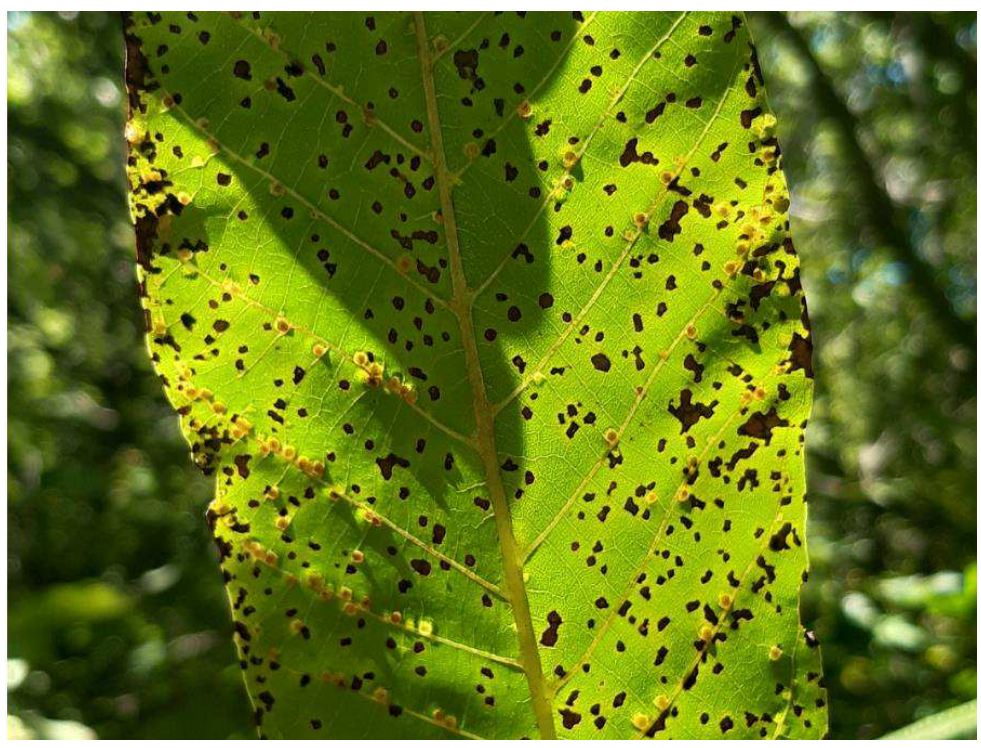

Fig. nr. 2 . Reprezentarea acarianului galicol al frunzelor de nuc (Aceria tristriata) pe partea posterioară a frunzei.

Acarianul iernează în faza de adult, femela depozitându-se în perioada rece a anului sub solzii mugurilor terminali ai ramurilor pomilor de nuc.

În cazul erinozei la plantațiile de nuc, semnele sunt vizibile pe suprafața superioară a frunzelor de nuc, unde pot fi văzute niște gale convexe de culoarea galbenă cu nuanțe roșii. Pe partea inferioară a frunzei în interiorul galelor, se pot observa niște perișori de culoare albă, 
care mai târziu capătă o nuanţă maro. În interiorul acestora, exemplarele Aceria erinea se întâlnesc depunându-și ouăle și dezvoltă noi generații de acarieni.

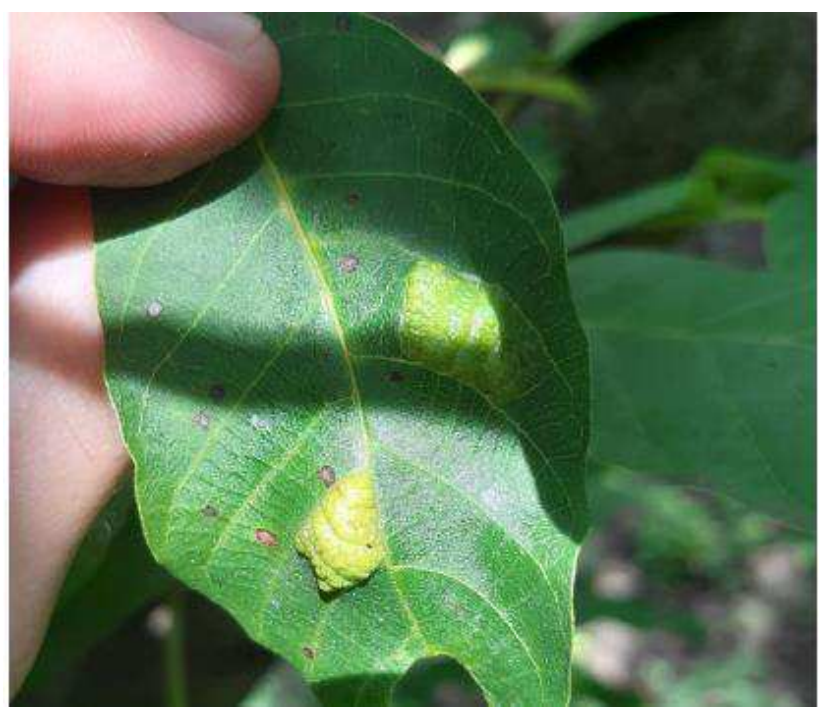

Fig. nr. 3. Reprezentarea erinozei (brasicarea) frunzelor de nuc, cauzată de către acarianul Aceria erinea pe partea anterioară a frunzei.

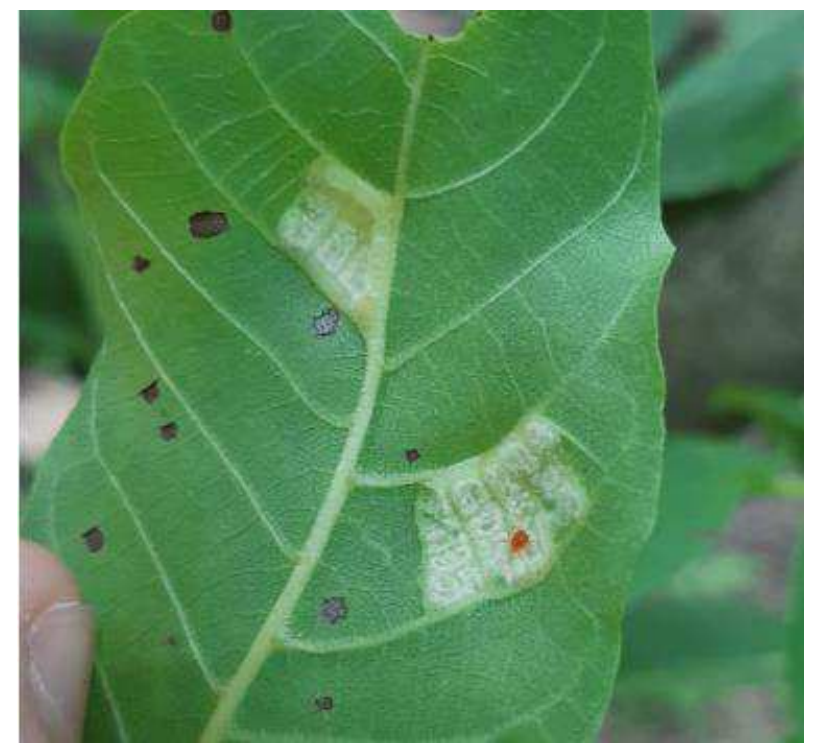

Fig. nr. 4. Reprezentarea erinozei (brasicarea) frunzelor de nuc, cauzată de către acarianul Aceria erinea pe partea posterioară a frunzei.

\section{Concluzii}

Drept concluzii trebuie de accentuat că cultura nuciferă are un loc de cinste cât alimentar, atât cultural și econimic; astfel protecția acestuia se impune ca o necesitate primordială. Reprezentanții clasei Arachnida chiar și dacă își manifestă activitatea distructivă asupra culturii sub pragul economic de dăunare, indiferent de acest fapt este necesară prelucrarea preventivă a pomilor. 
Această cultura nuciferă pe lângă patogenii și boala sus-numită mai dispune de o gamă largă de boli și dăunători care necesită cercetări minuțioase în scopul elaborării mijloacelor inofensive de protecție a culturii pentru o conviețiure armonioasă dintre tandemul om-mediu înconjurător.

\section{Bibliografie}

1. Gheţea L., Dumitrescu M., Toma N., 2002. ”Aspecte moleculare şi biochimice ale interacţiei gazdă - parazit în cadrul procesului tumorigen la plante,.. Gh.

Câmpeanu, I. F. Dumitru; ’Progrese in Biotehnologie,, vol.II,, http://ebooks.unibuc.ro/biologie/biotehnologie/ [4];

2. Î.S. "Centrul de Stat pentru Atestarea și Omologarea Produselor de Uz Fitosanitar și a Fertilizanților" [6];

3. Nicoleta Ianovici, Adina Matica, Mădălina Scurtu; " Contribution to the knowledge of leaf galls from western Romania,, 2010 [5];

4. Raportul National de Revizuire a Exportului Produselor Ecologice din Moldova: Nuci, Miere şi Cereale 2018 [3];

5. Шапа В. „Орех грецкий,, Chişinău 2002, pag. 10 [2];

6. http://www.euroavia-ge.com (Accesat pe data de 25.08.2020) [1];

7. https://www.horticultorul.ro/insecte-boli-daunatori-fungicide, [7]. 